\title{
MAKNA RAGAM HIAS PADA FASAD BANGUNAN (STUDI KASUS: KELENTENG BAN HING KIONG, MANADO)
}

\author{
Sintia Dewi Wulanningrum ${ }^{1}$ \\ ${ }^{1}$ Jurusan Arsitektur, Fakultas Teknik, Universitas Tarumanagara Jakarta \\ Pusat Studi Budaya Tionghoa, Universitas Tarumanagara \\ Email: sintiadewe@gmail.com/ sintiaw@ft.untar.ac.id
}

\begin{abstract}
Ban Hing Kiong Temple was founded in 1819 and is the oldest temple in North Sulawesi. The advantages of Ban Hing Kiong Temple are; strategically located at the center of the city that is reachable by public transportation and is the center of China Town where temples, houses, shrines and markets belonging to the Chinese ethnic can be found, as well as two cannons belonging to VOC, therefore, it is a religious center as much as it is a historical tourist destination. In addition, this temple possesses a unique design with Classical Chinese architectural style decorated with a variety of motifs. Motifs found in this Temple is one of many attractions for visitors. Motif is a basic form of decoration that will usually become a repeated pattern in a craft or art work (Purnomo, 2013). Every motif in Ban Hing Kiong Temple has different type and meaning. This research aims to identify the types and meanings of motifs on the exterior of Ban Hing Kiong Temple. The method used is descriptive qualitative by identifying the types of motifs and the meanings of motifs through literature studies and field survey. This study found that there are three types of motifs on the building exterior, including; flora motif, fauna motif, geometric and motif about legends. The most common motif found on the exterior is fauna motif in the form of dragon and tiger ornaments found in the building column, on building roofs, walls, and incense burners.
\end{abstract}

Keywords: motif, meaning, building exterior, temple

\begin{abstract}
ABSTRAK
Kelenteng Ban Hing Kiong berdiri sejak tahun 1819 dan merupakan Kelenteng tertua di Sulawesi Utara.. Kelebihan Kelenteng Ban Hing Kiong antara lain; letaknya strategis berada di tengah kota yang dapat ditempuh dengan transportasi umum dan merupakan pusat China Town yang terdapat terdapat kuil, rumah-rumah, tempat suci dan pasar milik etnis Cina, terdapat dua buah meriam peninggalan VOC, sehingga selain sebagai pusat religi juga sebagai tujuan wisata sejarah. Selain itu, Klenteng ini memiliki desain yang unik dengan gaya arsitektur Cina Klasik yang dihiasi dengan ragam ragam hias. Ragam hias yang ada di Kelenteng merupakan salah satu daya tarik bagi pengunjung. Ragam hias adalah bentuk dasar hiasan yang biasanya akan menjadi pola yang diulangulang dalam suatu karya kerajinan atau seni (Purnomo, 2013). Setiap ragam hias di Kelenteng Ban Hing Kiong memiliki tipe dan makna yang berbeda-beda. Penelitian bertujuan untuk mengidentifikasi jenis dan makna ragam hias pada fasad Kelenteng Ban Hing Kiong. Metode Penelitian adalah deskriptif kualitatif dengan mengidentifikasi jenis ragam hias serta makna ragam hias melalui studi pustaka dan survey lapangan. Hasil penelitian yaitu terdapat tiga jenis ragam hias pada fasad bangunan antara lain; ragam hias flora, ragam hias fauna, geometris dan ragam hias legenda. Ragam hias yang paling banyak ditemukan pada fasad yaitu ragam hias fauna berupa ornamen naga dan macan yang berada pada kolom bangunan, atap bangunan, dinding serta tempat pembakaran hio.
\end{abstract}

Kata kunci: ragam hias, makna, fasad bangunan, Kelenteng

\section{PENDAHULUAN}

Kelenteng Ban Hing Kiong berada di Jalan D.L. Panjaitan, Kecamatan Wenang, Manado, Sulawesi Utara dan merupakan Kelenteng tertua di Sulawesi Utara. Pada awalnya, istilah Kelenteng sering dikaitkan dengan bunyi lonceng atau genta yang dibunyikan pada penyelenggaraan upacara di bangunan suci, sehingga untuk memudahkan penyebutannya, dinamakan kelenteng (Widiastuti, 2012). Kelenteng digunakan sebagai tempat beribadah kepada Tuhan, nabi, dan arwah leluhur dari Konfusianisme, Taoisme, dan Buddhisme (Salim, 2012). Pada Kelenteng biasanya terdapat arca dari para dewa-dewi dari ketiga ajaran itu berada di bawah satu 
atap bangunan (Herwiratno, 2007). Menurut Handinoto (1990), Kelenteng tidak hanya sebagai tempat kehidupan keagamaan, tetapi juga merupakan ungkapan lahiriah penganutnya. Kelenteng Ban Hing Kiong berasal dari bahasa Tionghoa. Ban berarti banyak, Hing artinya berkat yang melimpah dan Kiong artinya istana. Jadi Ban Hing Kiong artinya istana atau tempat ibadah yang memilii banyak berkat. Kelenteng Ban Hing Kiong berdiri pada 1819, dan mengalami beberapa kali pemugaran pada tahun 1854-1859 dan 1895-1902. Pada tanggal 14 Maret 1970, kelenteng mengalami kebakaran dan menghanguskan bangunan utama kelenteng dan tahun 1971, kelenteng dibangun kembali. Pada 10 September 1994, melalui upacara Pwa Pwe (upacara sembahyang besar), kelenteng Ban Hing Kiong diresmikan kembali.

Kelenteng Ban Hing Kiong memiliki kelebihan antara lain; sebagai destinasi wisata sejarah dan religi, memiliki dua meriam peninggalan VOC, memiliki desain bangunan arsitektur Cina yang unik, dimana terdapat ragam hias pada eksterior maupun interior bangunan. Selain itu, dari segi tampilan memiliki desain yang unik dan dari segi warna menggunakan warna-warna dasar (merah,biru, hijau dan kuning). Masing-masing warna memiliki arti tersendiri. (Primayudha,N dan Harridy,P.(2014). Pada awalnya, ornamen-ornamen pada bangunan kelenteng merupakan ornamen yang lebih mengkhususkan pada sisi peribadatan, tanpa melihat sisi seni. Akan tetapi, semakin berkembangnya waktu dan jaman, kebudayaan menyerap sisi peribadatan, sehingga ornamen pada bangunan Kelenteng memiliki nafas kehidupan dan warna tersendiri (Zhu, 2008).

Kelenteng memiliki ornamen sebagai elemen pelengkap dalam karya arsitektur sehingga menarik. Ornamen Kelenteng juga menjadi sarana penyampaian konsep, ajaran, dan falsafah dalam kehidupan masyarakat. Ornamen bangunan Tiongkok biasanya terdiri dari ornamen bermotif hewan, tumbuhan, fenomena alam, lambang geometris, dan tokoh (Enrisca, 2008).

Budaya Cina yang telah ada sejak ribuan tahun memiliki simbolisasi pada aspek kehidupan, simbol ini terdiri dari simbol fisik dan simbol non fisik. Simbol fisik diwujudkan dalm bentuk ornamen atau ragam hias dan warna-warna pada bangunan dengan detail-detail ornamen yang berbeda-beda sesuai dengan makna (Moedijiono, 2011)

Ragam hias merupakan karya seni rupa yang diambil dari bentuk-bentuk flora, fauna, figuratif, dan bentuk geometris. Berdasarkan Purnomo (2013), ragam hias tersebut dapat diterapkan pada media dua dan tiga dimensi. Jenis-jenis ragam hias pada arsitektur Cina antara lain:

1. Ragam Hias Flora. Flora sebagai sumber objek motif ragam hias dapat dijumpai hampir di seluruh pulau di Indonesia. Ragam hias dengan motif flora mudah dijumpai pada barangbarang seni seperti batik, ukiran, dan tenunan.

2. Ragam Hias Fauna. Ragam hias fauna merupakan bentuk gambar motif yang diambil dari hewan tertentu. Hewan pada umumnya telah mengalami perubahan bentuk atau gaya. Beberapa hewan yang biasa dipakai sebagai objek ragam hias adalah kupu-kupu, burung, kadal, gajah, dan ikan. Ragam hias motif fauna telah mengalami deformasi namun tidak meninggalkan bentuk aslinya. Ragam hias fauna dapat dikombinasikan dengan motif flora dengan bentuk yang digayakan.

3. Ragam Hias Geometris. Ragam hias geometris merupakan motif hias yang dikembangkan dari bentuk-bentuk geometris dan kemudian digayakan sesuai dengan selera dan imajinasi pembuatnya. Ragam hias geometris dapat dibuat dengan menggabungkan bentuk-bentuk geometris ke dalam satu motif ragam hias.

4. Fenomena Alam. Fenomena alam yang sering digambarkan dalam ragam hias Cina adalah angin, hujan, bintang, langit, api, matahari dan bulan. Api digambarkan sebagai simbol terang dan kemurnian. Matahari dan bulan sebagai simbol keadilan dan kekuatan yang luar biasa. 
5. Legenda.Legenda adalah cerita yang dipercaya oleh beberapa penduduk setempat benarbenar terjadi, tetapi tidak dianggap suci atau sakral. Legenda yang sering ditemui pada bangunan Cina antara lain : legenda Delapan Dewa (Pat Sian) yang merupakan simbol panjang umur, kemakmuran dan kebahagiaan dan legenda Sepuluh Pengadilan Terakhir sebagai upaya untuk mengingatkan manusia untuk menjauhi tindakan kriminal.

Menurut Salim (2016) beberapa contoh motif ragam hias yang biasa digunakan dalam sebuah bangunan Kelenteng antar lain :

a. Motif Naga.

Motif Naga biasa dijumpai pada seni hias di Tiongkok, baik pada peninggalan arsitektural maupun pada porselin ataupun lukisanlukisan. Ciri-ciri motif naga Cina adalah mempunyai moncong yang bergerigi tajam, berkumis panjang dan jarang mempunyai tanduk yang bercabang seperti menjangan, berambut panjang seperti rambut kuda, badan panjang bersisik, bersirip atas dan mempunyai kaki seperti cakar elang dan ekor seperti burung merak atau bola api. Naga dalam mitologi Cina merupakan binatang yang nafasnya menyerupai angin. Suara naga dianggap halilintar dan dapat menciptakan hujan. Karena keaktifannya di langit maka kehadirannya dianggap Dewa Langit. Oleh karena itu motif naga pada Kelenteng dilambangkan sebagai Dewa Langit.

b. Burung Merak atau Phoenix.

Motif burung merak sering muncul pada seni hias Cina. Di Jawa motif merak sangat popular terutama pada seni batik daerah pesisiran seperti Cirebon, Pekalongan, dan Lasem. Burung merak apabila memekarkan ekornya akan membentuk setengah lingkaran yang berwarna-warni. Setengah lingkaran tersebut melambangkan matahari yang baru muncul ataupun yang akan tenggelam. Matahari yang timbul-tenggelam dapat diartikan dengan siklus kehidupan, kelahiran, dan kematian manusia. Selain itu matahari melambangkan unsur yang atau dunia atas.

c. Motif Qilin.

Qilin adalah hewan mistik masyarakat Cina yang melambangkan nasib baik, kebesaran hati, panjang umur serta kebijaksanaan. Hewan ini sering digambarkan memiliki kepala naga berbadan rusa, surai dan ekor seperti harimau, serta memiliki 5 warna. Dengan demikian motif Qilin merupakan persatuan antara yin dan yang yang berarti kesempurnaan. Kedatangan Qilin selalu dianggap membawa berkah kebahagiaan dan keberuntungan (Hugus, 2008).

d. Motif Bunga Teratai .

Teratai merah bahasa ilmiahnya disebut Nelumbium nelumbo sering juga disebut bunga Padma. Ciri-cirinya daun lebar terkesan ditiup angin bergelombang dan menjulang ke atas tumbuh dari air daun bunganya sebagaian mekar dan sebagian masih terkatup dan lancip tanpa batang kayu atau ranting. Motif hiasan bunga teratai merah juga digambarkan dalam bentuk tiga dimensi. Teratai dalam seni hias Cina melambangkan kesucian dan kesempurnaan.

Sedangkan Simbol non fisik dapat dilihat dari prosesi-prosesi maupun kebiasaankebiasaan yang berlaku terutama pada prosesi-prosesi ritual. Aspek Non-fisik pada Arsitektur Kelenteng menurut Adhiwigno terdiri dari: Fengshui dan Konfusianisme. Fengshui merupakan metode untuk menentukan arah serta orientasi dari suatu kota, rumah, dan bangunan-bangunan lain dengan tujuan memperoleh energi (Qi) dari elemen-elemen alam pada lansekap seperti air, tanah, api, dan angin, serta elemen-elemen celestial seperti langit dan matahari. Pemikiran dari ajaran Konfusianisme diterapkan melalui penggunaan courtyard pada bangunan-bangunan Tionghoa. 


\section{Rumusan Masalah.}

Sebagai salah satu destinasi wisata religi dan sejarah di Manado, kelenteng Ban Hing Kiong memiliki daya tarik tersendiri, salah satunya pada arsitektur Cina pada bangunan. Salah satu bentuk Arsitektur Cina pada kelenteng yaitu penggunaan ragam hias. Ragam hias atau ornamen yang berada di Kelenteng, khususnya pada fasad depan bangunan, merupakan salah satu daya tarik bagi pengunjung. Ragam hias atau ornamen yang terdapat di Kelenteng Ban Hing Kiong memiliki makna dan dapat dikategorikan sesuai dengan jenisnya masing-masing. Rumusan masalah adalah bagaimanakah jenis dan makna ragam hias yang terdapat di Kelenteng Ban Hing Kiong Manado.Tujuan penelitian ini adalah untuk mengidentifikasi jenis dan makna ragam hias pada fasad Kelenteng Ban Hing Kiong serta mengetahui jenis ragam hias yang paling banyak terdapat pada fasad bangunan.

\section{METODE PENELITIAN}

Metode penelitian yang digunakan yaitu kualitatif deskriptif melalui identifikasi jenis dan makna ragam hias di Kelenteng Ban Hing Kiong. Pengumpulan data diperoleh dari sumber primer dan sekunder. Sumber primer berasal dari survey langsung ke Kelenteng Ban Hing Kiong dan wawancara ke pengelola Kelenteng. Sedangkan sumber data sekunder diperoleh dari buku dan jurnal yang berkaitan dengan kebudayaan Cina khususnya bangunan Kelenteng. Setelah mengumpulkan data mengenai makna dan jenis ragam hias, kemudian makna ragam hias diklasifikasikan berdasarkan jenisnya.

\section{Lokasi Pengambilan Data}

Penelitian dilakukan di Kelenteng Ban Hing Kiong, yang berada di jalan D.L. Panjaitan, Kecamatan Wenang, Manado. Fokus penelitian pada fasad bangunan Kelenteng yang meliputi: gerbang masuk; dinding, pintu, kolom, patung, atap depan, tempat pembakaran abu yang berada di depan bangunan.

\section{HASIL DAN PEMBAHASAN}

Ragam hias adalah bentuk dasar hiasan yang biasanya akan menjadi pola yang diulangulang dalam suatu karya kerajinan atau seni (Purnomo, 2013). Klasifikasi ragam hias di Kelenteng Ban Hing Kiong berdasarkan jenisnya dapat dibedakan menjadi tiga yaitu:

1. Ragam Hias Fauna.Ragam hias fauna merupakan ragam hias yang berasal dari bentuk hewan atau fauna. Pada arsitektur Cina ragam hias fauna seperti naga, singa, qilin dan lain sebagainya. Ragam hias fauna atau hewan yang terdapat pada fasad Kelenteng Ban Hing Kiong antara lain ornamen naga, qilin, macan, burung hong, katak, burung api dan ekor walet.

a. Ornamen naga.

Ornamen naga pada atap bangunan merupakan simbol kekuatan, keadilan dan kekuasaan. Bagi masyarakat Cina naga merupakan hewan yang paling sering digunakan sebagai ragam hias karena dipercaya memiliki tenaga yang berubah-ubah dan sangat berkuasa. Ciri-ciri motif naga adalah memiliki moncong yang bergerigi tajam, berkumis panjang, berambut panjang seperti kuda, badan panjang bersisik, bersirip atas dan mempunyai kaki seperti cakar elang dan ekor seperti bola api atau burung merak. Menurut mitologi Cina, naga merupakan binatang dengan nafas menyerupai angin, suara seperti halilintar serta dapat menciptakan hujan. Oleh sebab itu, naga dianggap sebagai dewa langit karena sifatnya. Motif naga pada kelenteng dilambangkan sebagai dewa langit. Ragam hias fauna atau hewan terdapat ornamen naga dengan mayoritas warna kuning yang saling berhadapan serta warna hijau. Warna 
kuning pada ornamen naga merupakn simbol unsur tanah $(\mathrm{Tu})$ yang melambangkan kekuatan dan keabadian. Warna hijau merupakan simbol dari unsur kayu yang melambangkan panjang umur, pertumbuhan dan keabadian.

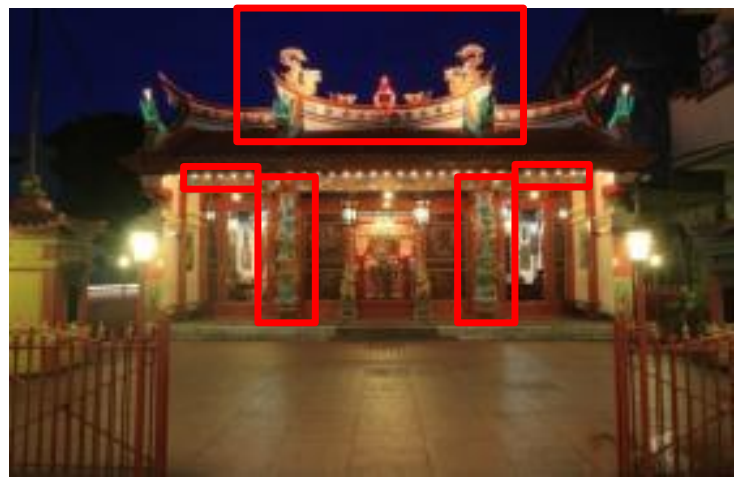

Gambar 1. Perletakkan ornamen naga di fasad depan

Pada atap bangunan utama terlihat bubungan berbentuk ekor walet dan terdapat dua patung keramik naga yang berhadapan dengan patung buah labu yang berada diantara ke dua naga. Naga pada atap bangunan melambangkan kekuatan dewa-dewa.

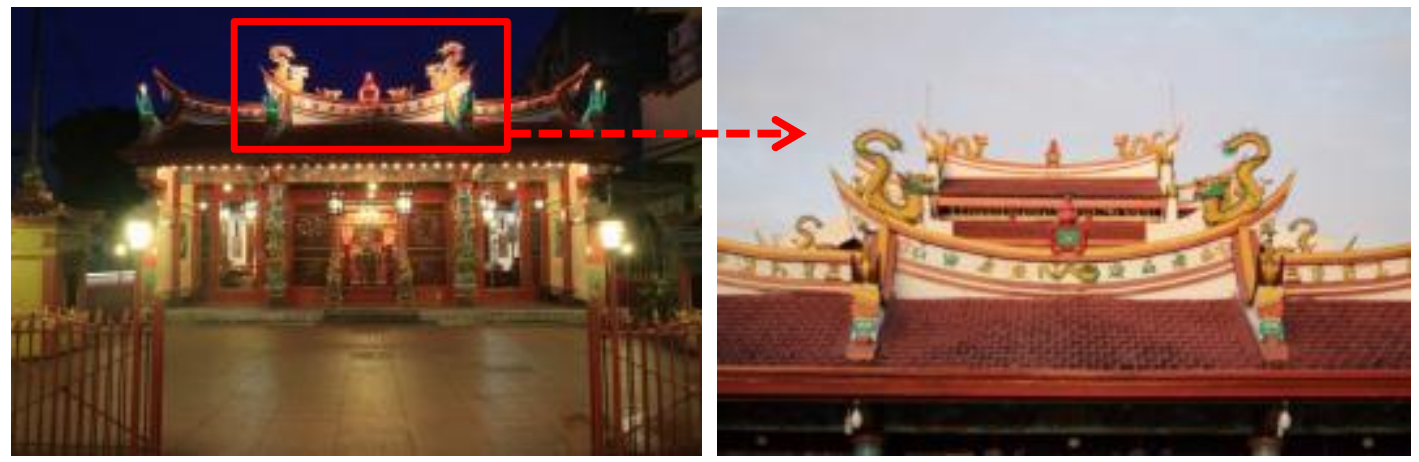

Gambar 2. Ornamen naga di atap

Ornamen naga pada kolom berada di fasad depan bangunan dan berjumlah dua buah. Ornamen ini menjulur dari atas sampai bawah kolom. Mayoritas ornamen naga berwarna kuning yang melambangkan kekuatan dan kekuasaan.

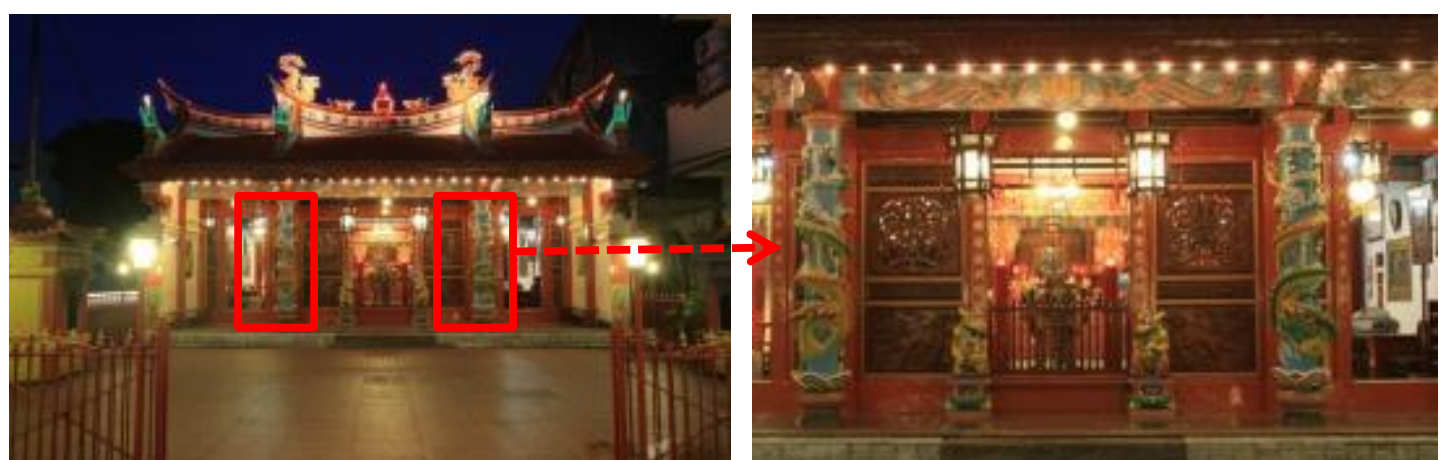


Gambar 3. Perletakkan ornamen naga di kolom

b. Ornamen Burung Hong.

Pada fasad depan Kelenteng terdapat ornamen Burung Hong, dengan warna kuning dan hijau. Burung Hong mempunyai makna kesetiaan, ketulusan hati, keadilan dan kemanusian. Pada umumnya Burung Hong terdiri dari tiga warna. Sedangkan warna burung hong pada fasad bangunan Kelenteng Ban Hing Kiong terdiri dari tiga unsur warna yaitu kuning, hijau dan merah. Warna kuning merupakan simbol dari unsur tanah yang melambangkan kekuatan dan kekuasan, warna hijau merupakan simbol dari unsur kayu yang melambangkan panjang umur, pertumbuhan dan keabadian. Sedangkan warna merah merupakan simbol dari api yang melambangkan kegembiran, keberuntungan dan kebahagiaan.

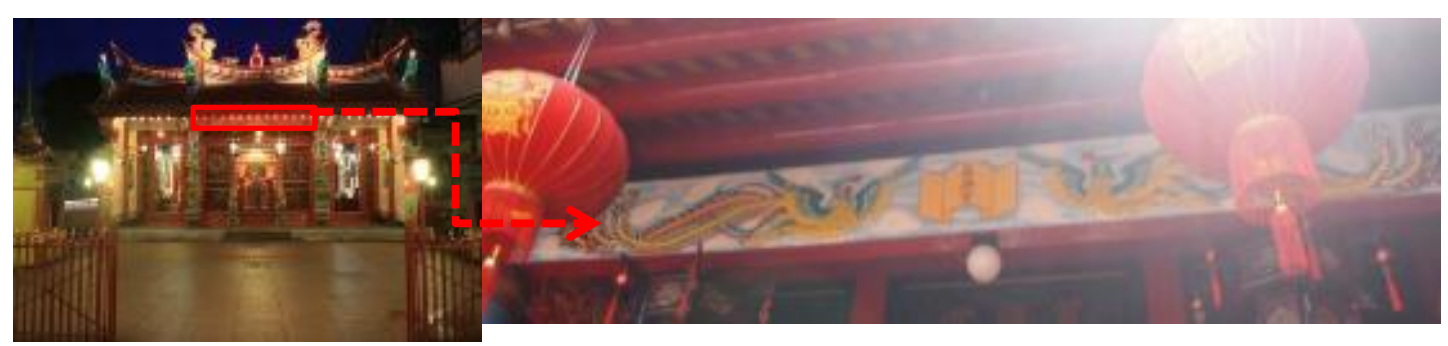

Gambar 4. Perletakkan ornamen burung hong

c. Ornamen Qilin.

Ornamen qilin atau kirin pada fasad bangunan berada di dinding depan kelenteng. Pada kepercayaan masyarakat Cina di Hongkong, Macau, dan Asia Tenggara, Kirin sering digunakan sebagai benda dan ornamen hongshui untuk mendatangkan kemakmuran, penangkal kejahatan, dan tidak pernah digunakan untuk melukai orang lain. Qilin merupakan hewan mistis masyarakat Cina yang melambangkan kebesaran hati, panjang umut dan kebijaksanaan. Qilin yang berada pada dinding depan kelenteng berwarna coklat karena mengikuti bahan material dinding yang terbuat dari kayu. Pada arsitektur Cina, material kayu sering digunakan sebagai sistem struktur serta elemen arsitektur seperti pada penutup lantai, jendela, pintu dan dinding bangunan.
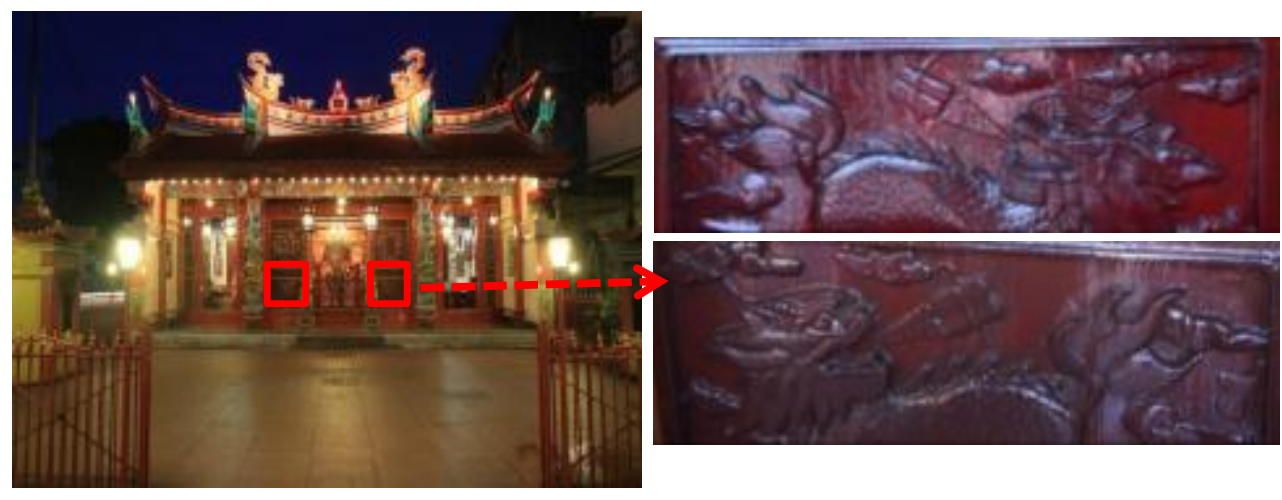
Gambar 5. Perletakkan ornamen Qilin pada dinding depan kelenteng

d. Patung Macan.

Patung macan berjumlah dua buah yang berada di depan pintu masuk utama kelenteng (gambar 7) dan diatas tempat pembakan hio atau hiolo (gambar 8). Patung macan yang berada di Kelenteng Ban Hing Kiong terdiri dari macan jantan dan macan betina. macan memiliki makna keadilan dan kejujuran hati. Hiolo berornamen naga merupakan tempat pembakaran hio untuk menghormati dewa. Patung macan pengapit hiolo melambangkan kekuatan agung dan keberanian yang menjaga nama baik Dewi Samudera. Sedangkan warna pada patung macan terdiri dari warna kuning yang merupakan warna dominan, warna hijau, putih dan merah. Warna kuning merupakan simbol dari unsur tanah yang melambangkan kekuatan dan kekuasan, warna hijau merupakan simbol dari unsur kayu yang melambangkan panjang umur, pertumbuhan dan keabadian. Warna merah pada patung merupakan simbol dari api yang melambangkan kegembiran, keberuntungan dan kebahagiaan. Sedangkan warna putih merupakan simbol dari unsur logam, yang melambangkan kedukaan dan kesucian.
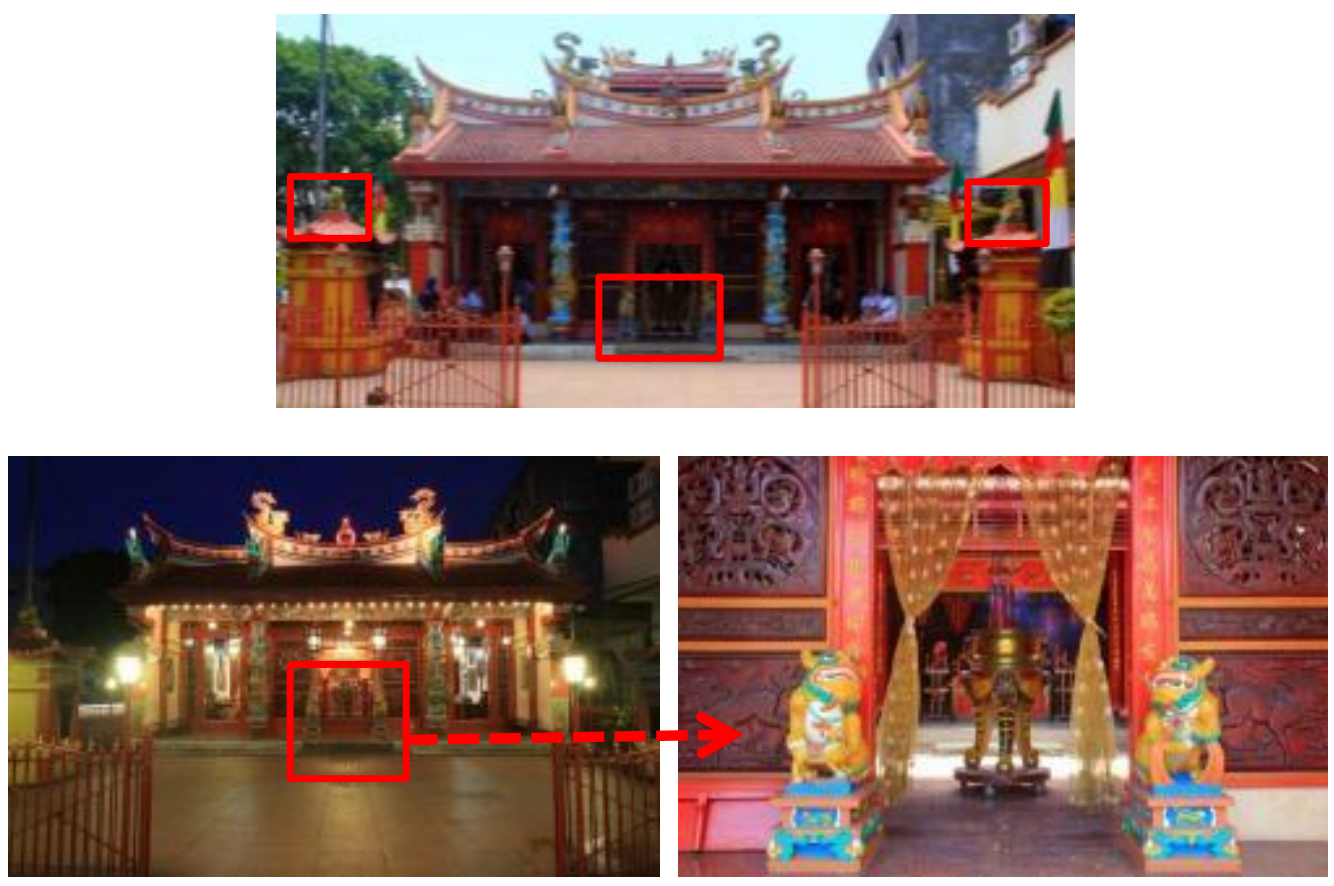

Gambar 7. Perletakkan ornamen macan di pintu masuk utama

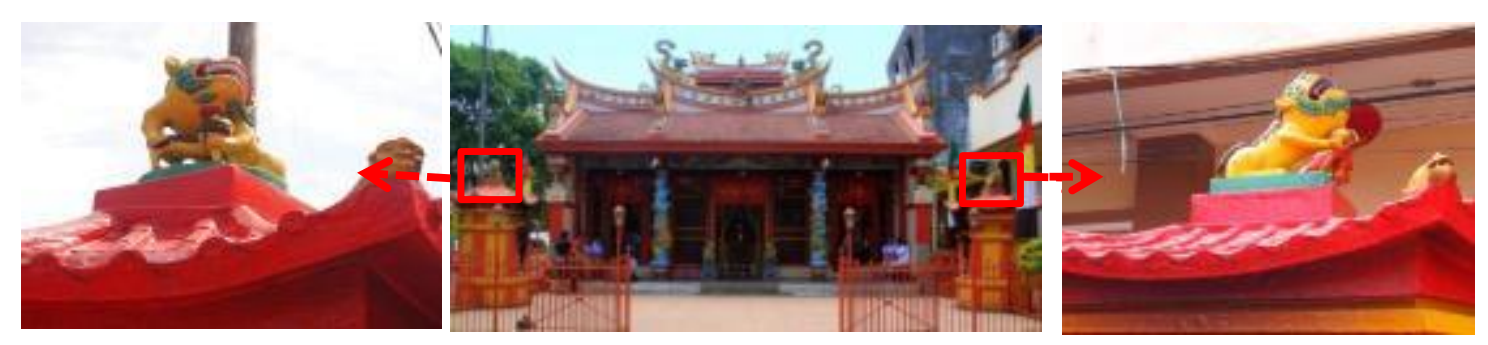

Gambar 8. Perletakkan ornamen macan di tungku pembakaran hio 
e. Ekor Walet.

Bentuk atap yang menyerupai perahu dengan ujung atap berupa ekor walet merupakan lambang dari kemakmuran. Ekor walet terdiri dari warna kuning, merah dan hijau. Warna kuning merupakan simbol dari unsur tanah yang melambangkan kekuatan dan kekuasan, warna hijau merupakan simbol dari unsur kayu yang melambangkan panjang umur, pertumbuhan dan keabadian. Warna merah pada patung merupakan simbol dari api yang melambangkan kegembiran, keberuntungan dan kebahagiaan.

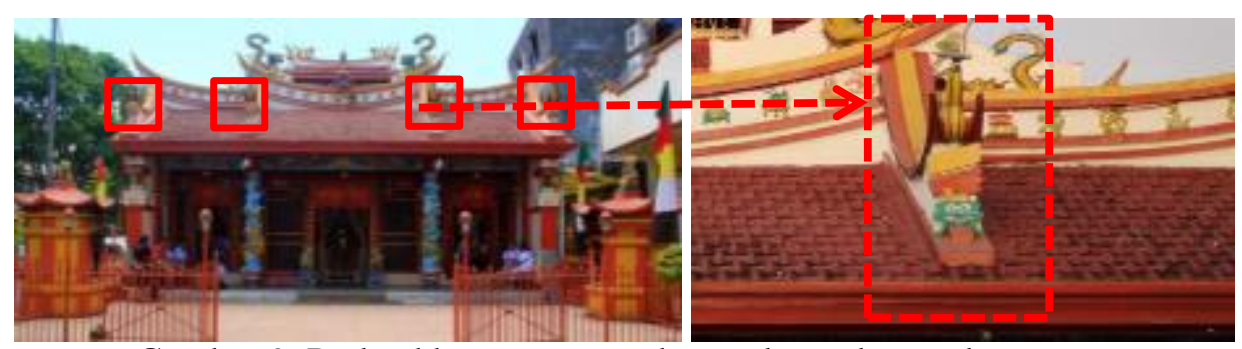

Gambar 9. Perletakkan ornamen ekor walet pada atap bangunan

f. Katak.

Katak yang terdapat pada atap merupakan simbol air pada kehidupan dan dipercaya dapat mendatangkan hujan. Hujan bagi masyarakat Cina merupakan simbol keberkahan hidup.warna kuning emas pada katak melambangkan melambangkan kegembiran, keberuntungan dan kebahagiaan dan rejeki.

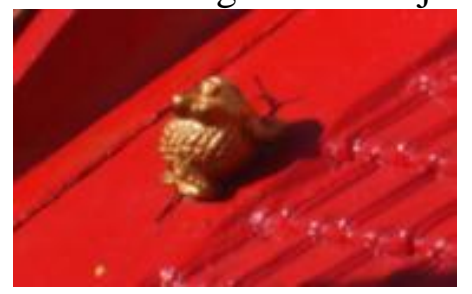

Gambar 10. Perletakkan ornamen katak pada atap bangunan

g. Burung api atau $\mathrm{Cu}$ Chiok

Burung api warna merah yang berada di atap depan kelenteng merupakan simbol dari keabadian, siklus kehidupan setelah mati dan simbol dari kebangkitan tubuh setelah mati dan simbol dari kebahagiaan. 


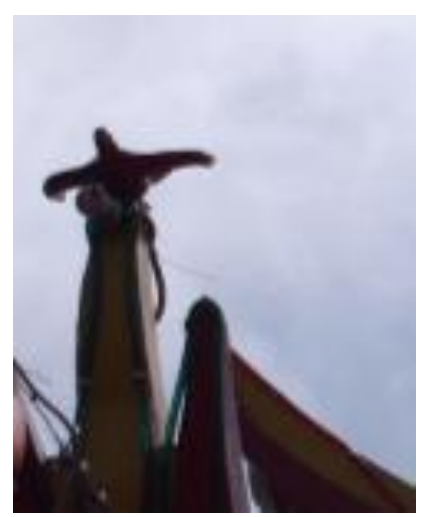

Gambar 9. Perletakkan ornamen burung api

2. Ragam Hias Flora.

a. Ornamen bentuk labu

Patung buah labu atau buli-buli, berada tepat ditengah-tengah nok atap utama. Hal ini dipercaya sebagai kekuatan untuk menjaga lingkungan dari pengaruh jahat yang hendak masuk merusak atmosfir Kelenteng. Warna dominan pada labu adalah warna merah. Warna merah pada ornamen merupakan simbol dari api yang melambangkan kegembiran, keberuntungan dan kebahagiaan, simbol untuk menjaga keseimbangan feng-shui dan menangkal pengaruh jahat, serta lambang pengobatan.

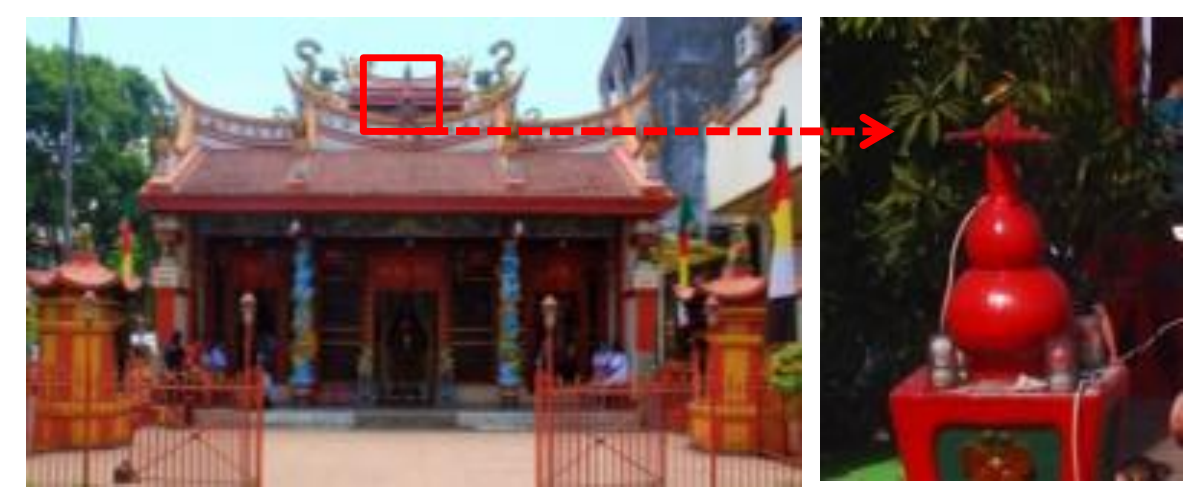

Gambar 10. Perletakkan ornamen labu di atap

b. Ornamen daun dan bunga

Ragam hias flora pada Kelenteng antara lain; bentuk daun yang merupakan simbol keindahan, bunga anggrek melambangkan cinta kasih dan kehalusan; bunga krisan yang melambangkan kebahagian dan musim gugur; peoni yang merupakan simbol musim semi, kasih sayang dan keberuntungan; bambu sebagai simbol umur panjang, daya tahan dan kesabaran. Ornamen daun pada kolom bangunan berfungsi untuk menambah keindahan pada kelenteng. 

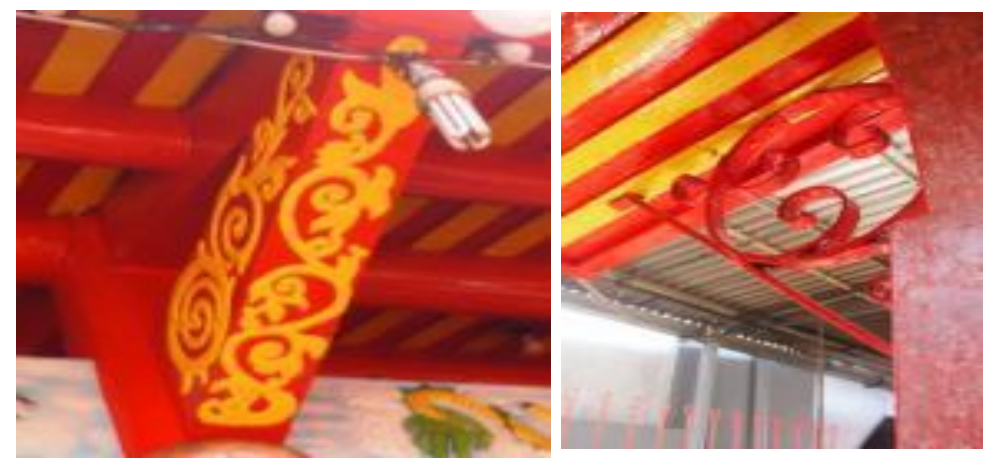

Gambar 11. Perletakkan ornamen daun

c. Ragam Hias Geometris

Ornamen lambang geometris Yin Yang yang berada pada atap gerbang masuk utama Kelenteng bermakna menjaga dari pengaruh buruk. Bentuk geometris pada ornamen di Kelenteng merupakan lambang Yin dan Yang. Ornamen geometris ini diharapkan mampu menangkal pengaruh buruk serta mendatangkan kemakmuran dan keselamatan. Warna dari regam hias geometris yaitu coklat, yang disesuaikan dengan bahan material yang berasal dari kayu.

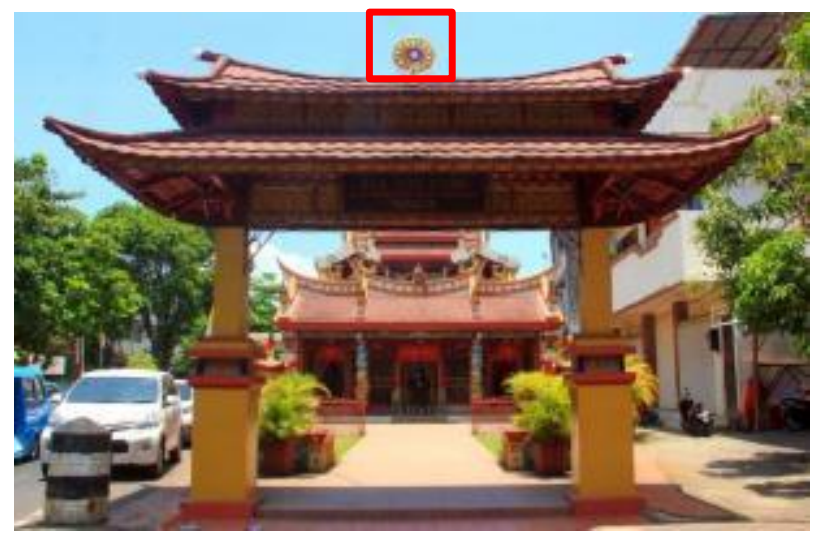

Gambar 12. Perletakkan ornamen geometris pada gerbang utama

Ragam hias geometris pada kelenteng terdapat pada hiasan atap dan dinding atas bangunan. Bentuk untuk bangunan. ornamen uang atap bangunan

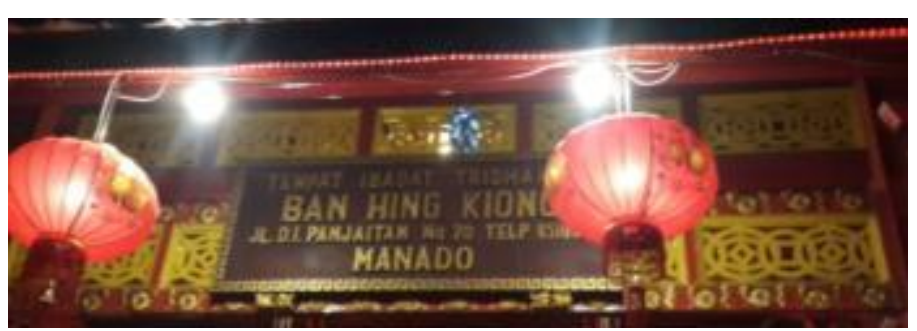
geometris digunakan memperindah Selain itu terdapat logam pada ornamen yang merupakan 
simbol keberkahan dan rejeki.

Gambar 13. Perletakkan ornamen geometris uang pada gerbang utama

d. Ragam Hias Legenda

Ragam hias legenda berupa ragam hias delapan dewa (gambar 14) atau Pat Sian. Pat Sian merupakan simbol keberuntungan, panjang umur, kemakmuran dan kebahagiaan bagi masyarakat Tionghoa. Masing-masing dewa mewakili delapan kondisi kehidupan. Ragam hias delapan dewa terdapat pada ornamen kolom depan bangunan, berada pada ornamen atap bangunan dan berada pada ornamen interior kelenteng. Pada ragam hias delapan dewa memiliki warna kuning, hijau dan merah. Warna kuning merupakan simbol dari unsur tanah yang melambangkan kekuatan dan kekuasan, warna hijau merupakan simbol dari unsur kayu yang melambangkan panjang umur, pertumbuhan dan keabadian. Warna merah pada patung merupakan simbol dari api yang melambangkan kegembiran, keberuntungan dan kebahagiaan.

\section{KESIMPULAN}

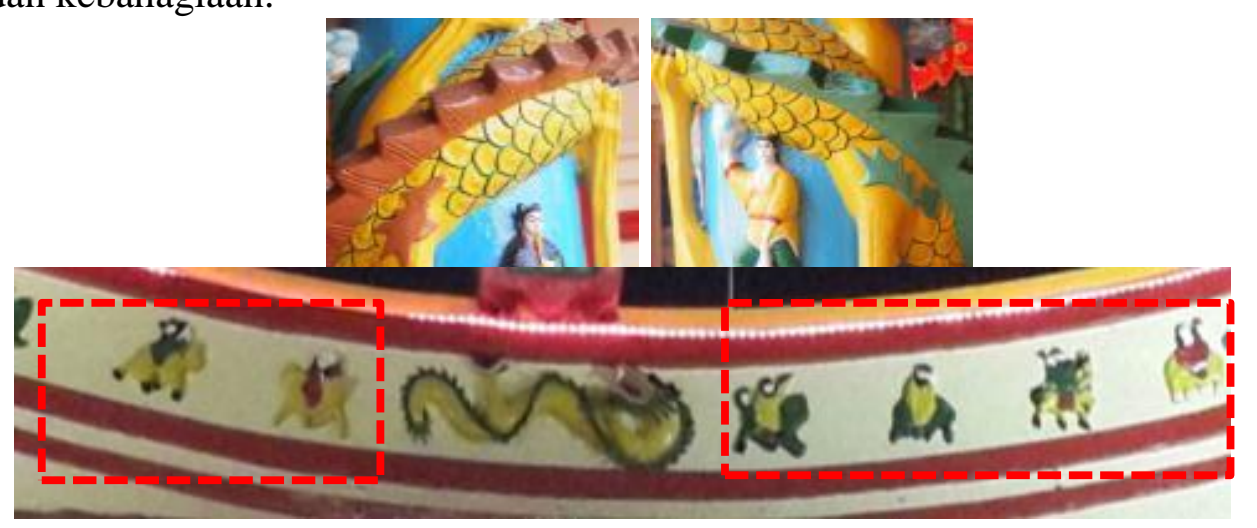

Gambar 14. Ragam hias Delapan Dewa

Jenis ragam hias atau ornamen yang terdapat pada fasad Kelenteng Ban Hing Kiong yaitu ragam hias flora, fauna, geometris dan legenda. Ragam hias flora terdapat pada ornamen pintu, ragam hias fauna terdapat pada atap, kolom serta patung, sedangkan ragam hias fauna berada pada ornamen dinding depan, pintu masuk dan pintu gerbang. Ragam hias geometris berada pada gerbang utama sedangkan ragam hias legenda delapan dewa terdapat pada atap bangunan dan kolom pada pintu masuk utama. Ragam hias fauna yang terdapat di kelenteng Ban Hing Kiong antara lain ornamen naga, burung hong, qilin, macan, burung api, ekor walet dan katak. Ragam hias flora yang berada di kelenteng antara lain ornamen labu, bunga dan daun. Ragam hias legenda pada kelenteng yaitu ragam hias delapan dewa yang menggambarkan delapan kehidupan manusia. Sedangkan ragam hias geometris berupa bentuk geometris yang melambangkan unsur Yin dan Yang serta ragam hias berbentuk uang logam. Ragam hias yang paling banyak ditemukan pada fasad bangunan adalah ragam hias fauna yang berupa ornamen naga yang berada pada atap, kolom dan dinding bangunan. Naga merupakan merupakan simbol kekuatan, keadilan dan kekuasaan Sedangkan sebagian besar warna ragam hias yang terdapat di fasad bangunan memiliki warna 
kuning. Warna kuning merupakan simbol dari unsur tanah yang melambangkan kekuatan dan kekuasan.

\section{Saran}

Penelitian selanjutnya dapat membahas mengenai perbedaan ragam hias pada fasad kelenteng-kelenteng di Manado.Diharapkan adanya penelitian mengenai akulturasi kebudayaan Cina dan kebudayaan Manado yang berada di kelenteng.

\section{Ucapan Terima Kasih (Acknowledgement)}

Terima kasih kepada Pusat Studi Budaya Tionghoa yang telah mengijinkan untuk berpartisipasi dalam kegiatan penelitian pada Kelenteng Ban Hing Kiong Manado, sehingga penelitian ini dapat berjalan lancar dan kepada pengelola Kelenteng Ban Hing Kiong yang telah memberikan informasi yang begitu banyak dan bermanfaat mengenai sejarah serta makna ragam hias kelenteng.

\section{REFERENSI}

Djoko, D. \&Hetroyani. (2013). Yin Yang, Chi dan Wu Xing pada arsitektur kelenteng; studi kasus: kelenteng sebelum abad 19 di Lasem, Rembang dan Semarang". Jurnal Ilmiah UNTAG Semarang, 2(3).

Erisca, N. (2008). Kelenteng Tanjung Kait (Tinjauan Arsitektural dan Ornamentasi). Depok: Fakultas Ilmu Pengetahuan Budaya Universitas Indoenesia (UI).

Handinoto (1990). Sekilas tentang arsitektur Cina pada akhir abad ke XIX di Pasurua. Jurnal Dimensi Arsitektur, 15.

Herwiratno, M. (2007). "Kelenteng: Benteng terakhir dan titik awal perkembangan kebudayaan Tionghoa di Indonesia". Jurnal Lingua Cultura, 1(1), 78-86.

Moedjiono. (2011). Ragam hias dan warna sebagai simbol dalam arsitektur Cina. Jurnal Universital Diponegoro, 11, hal. 19-20.

Jin, P. (2007). Kebudayaan Naga Cina. Chong Qing:Chong Qing PublisHing Group.

Primayudha, N, et al. (2014).Simbol dan makna bentuk naga (Studi kasus: Vihara Satya Budhi Bandung). Jurnal Rekajiva. Desain Interior Itenas , 2(1).

Purnomo, Eko, et al. (2013). Seni Budaya. Jakarta: Kementrian Pendidikan dan Kebudayaan Republik Indonesia.

Salim, P. (2012). Arsitektur Cina pada klenteng Jin De Yuan di kawasan Pecinan Jakarta sebagai suatu perwujudan akulturasi kebudayaan. Jurnal Humaniora, 3(2), 413-421.

Salim, P. (2016). Memaknai pengaplikasian ornamen pada atap bangunan klenteng sebagai ciri khas budaya Tionghoa. Jurnal Aksen 1(2). 50-64

Too, L.(2000). Penerapan Feng Shui, Pa Kwa dan Lo Shu. Jakarta: PT. Elex Media Kompuntindo.

Yoswara, H. (2011), Simbol dan makna bentuk naga (Studi kasus: Vihara Satya Budhi Bandung). Jurnal Desain FSRD ITB, Bandung, 2.

Widiastuti, Kurnia, et al. (2012), Karakteristik arsitektur kelenteng Sutji Nurani, Banjarmasin, Jurnal Arsitektur Program Studi Teknik Arsitektur Universitas Lambung Mangkurat 1(1).

Zhu, L. (2008). Kajian Unsur-unsur Dekorasi Tradisional Arsitektur Cina Kuno dengan Dekorasi Kuil dan Hubungannya dengan Psikologi. Nan Chang: Nan Chang University. 